\title{
URINARY WHITE CELL EXCRETION IN CHILDHOOD
}

\author{
BY \\ I. B. HOUSTON \\ From the Department of Child Health, St. Mary's Hospital, Manchester 13
}

(RECEIVED FOR PUBLICATION OCTOBER 8, 1964)

In recent years more attention has been paid to the diagnosis of pyelonephritis, and this has made accurate estimation of pyuria more necessary. Houghton and Pears (1957), Hutt, Chalmers, MacDonald, and de Wardener (1961), and Little (1962) have all reported their experience in measuring the rate of urinary white cell excretion. Their figures are very largely derived from adults; the present report is designed to provide a comparable set of values during infancy and childhood. Such figures have a direct relevance to the diagnosis of chronic pyelonephritis, other renal diseases, and also to the interpretation of the 'prednisolone provocative test' (Little and de Wardener, 1962; Katz, Velasquez, and Bourdo, 1962) when this is performed on a child.

\section{Material and Methods}

Carefully timed specimens of urine were collected by a clean voiding technique from 141 children ( 85 male, 56 female) of varying ages. The problems inherent in collecting timed specimens of urine from small infants necessitate their presence in hospital, and in consequence the urine specimens were collected from children already in hospital convalescing from a variety of illnesses. Any child who was febrile, who had had any disease remotely likely to influence the cellular composition of the urine, or who was receiving steroid, antibiotic, or salicylate therapy was excluded from the study.

For continent children able to micturate on request there is no problem about collecting a timed specimen of urine, though with some it is preferable to allow them to micturate spontaneously, carefully noting the times. In consequence, though most specimens were collected over an interval of two hours, there was a variation of 23 to 267 minutes.

Incontinent infants and toddlers present greater difficulties; these were surmounted by using a special machine which gave immediate audible warning of the fact that an infant had micturated. The time of passing the first specimen was noted and the specimen was discarded. The next time micturition occurred the specimen was collected, unless the time interval between specimens was less than an hour, in which case more specimens were collected and pooled together for exami- nation, the total time being carefully noted. The duration of these specimens varied from 60 to 290 minutes.

The white cell excretion rate of each urine specimen was determined by the method of Houghton and Pears (1957). A few minor modifications in technique were made: $10 \mathrm{ml}$. urine were centrifuged at 2,000 r.p.m. for 10 minutes and the sediment resuspended in $0.5 \mathrm{ml}$. fluid (instead of $1 \mathrm{ml}$.) thus concentrating the urine 20 times. This was found generally to produce a more convenient concentration of white cells for counting in a Fuchs-Rosenthal chamber. An attempt was made to count only leucocytes and, to facilitate this, 2 drops of $0.1 \%$ Nile-blue stain were allowed to dry on the cover slip before use.

The height, weight, and age of each child were noted and their body surface area calculated from nomograms.

\section{Results}

In Figs. 1-4 the urinary white cell excretion rates are plotted against the age, height, weight, and surface area of individual patients. There is clearly a relation between white cell excretion and the individual's size, best shown in respect of height and surface area. Six of the values are so different, however, that it must be assumed that these patients had pathologically raised excretion rates. Careful reappraisal of these cases has not revealed a cause; one was awaiting tonsillectomy, the others suffered respectively from asthma, Fallot's tetralogy, idiopathic thrombocytopenic purpura, temporal lobe epilepsy, and muscular dystrophy.

In 20 patients, further estimates of the white cell excretion rate were made at intervals varying between 3 days and 6 months. 13 patients had two, 5 patients three, 1 four, and 1 five specimens of urine collected. The results are shown in Table 1 . In 15 patients the initial result was within the normal range and so were all except one of the subsequent values, though they sometimes varied considerably from the original one. Of the 6 patients with unusually high values, 5 had repeat estimates performed: 2 remained abnormal and the others became normal.

In 5 children consecutive urine specimens were collected over a complete 24-hour period (Table 2). 


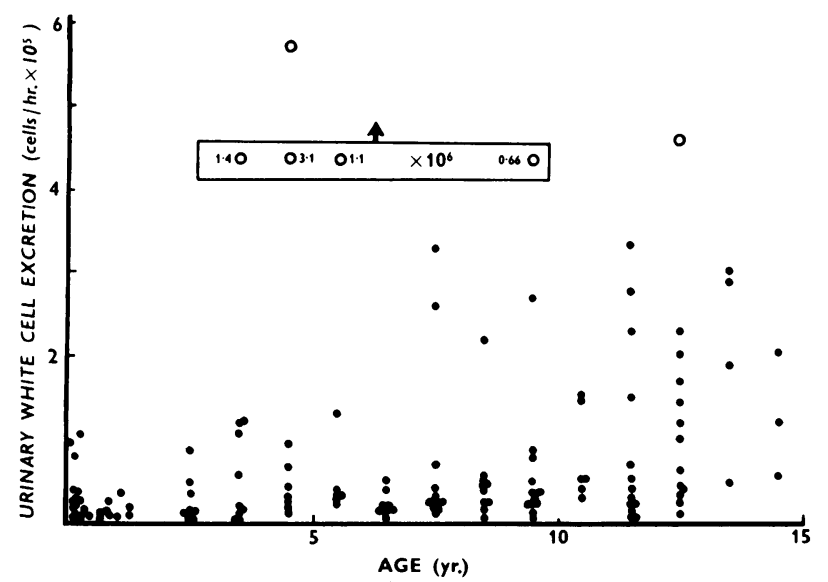

FIG. 1.-Relationship of white cell excretion to age. In the first two years of life, age is plotted to the nearest month. The rings represent fortuitously abnormal results.

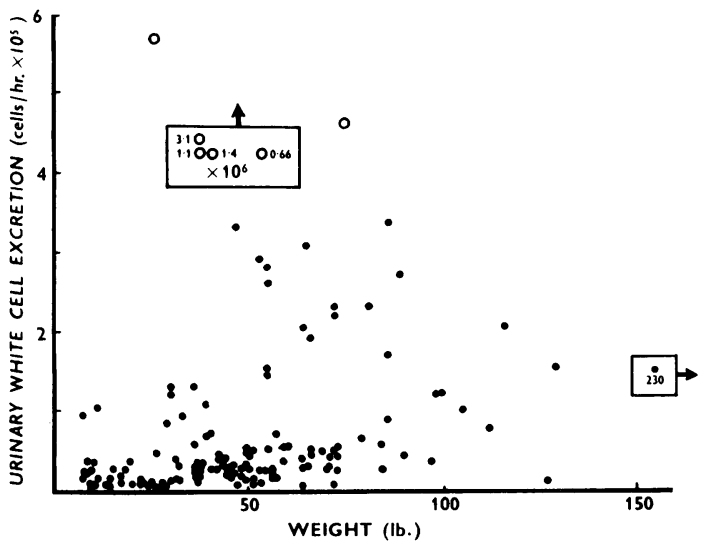

FIG. 2.-Relationship of white cell excretion to weight.

There was sometimes a five- or sixfold difference between minimal and maximal excretion rates in any one day, but there was sufficient consistency in the results to define whether the figures fell, over-all, into a normal or abnormal pattern. Some of this variation could be due to the failure of some children to empty their bladders completely when micturating; collection by catheter would obviate this possibility but cannot be justified in view of the known risks of the procedure.

\section{Discussion}

Hodson, Drewe, Karn, and King (1962) have shown that, in childhood, the length and crosssectional area of the kidneys are closely related to the child's height and weight, especially the height. The present study suggests that urinary white cell excretion is also a function of body size and,

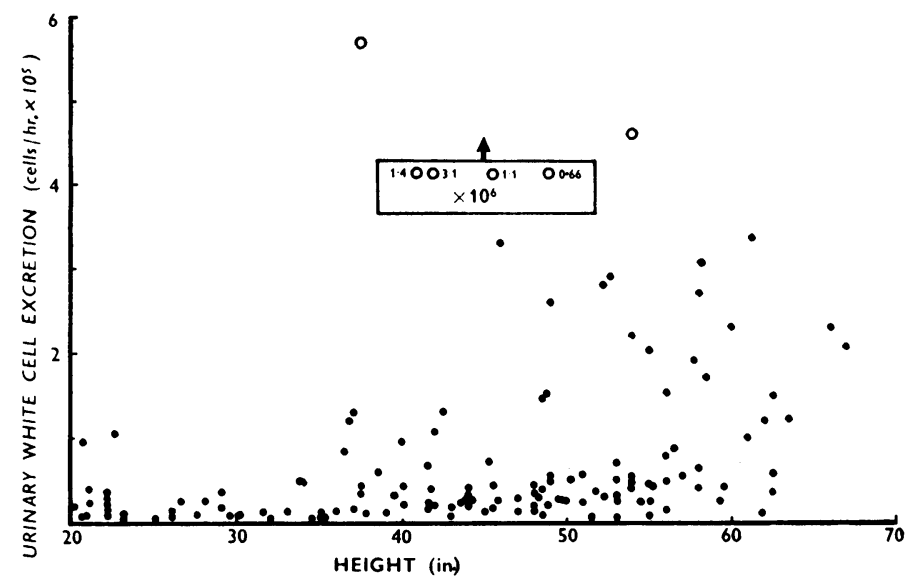

FIG. 3.-Relationship of white cell excretion to height. 
TABLE 1

URINARY WHITE CELL EXCRETION RATES FROM INDIVIDUAL PATIENTS WITH VARYING INTERVALS BETWEEN SPECIMENS

\begin{tabular}{|c|c|c|c|c|c|}
\hline \multirow{2}{*}{ Patient } & \multicolumn{5}{|c|}{ Urinary White Cell Excretion (cells/hr.) } \\
\hline & 1 & 2 & 3 & 4 & 5 \\
\hline $\begin{array}{l}\text { A.M. } \\
\text { P.R. } \\
\text { D.Br. } \\
\text { M.B. } \\
\text { A.D. } \\
\text { T.P. } \\
\text { R.M. } \\
\text { B.N. } \\
\text { W.St.L. } \\
\text { P.C. } \\
\text { M.J. } \\
\text { A.J. } \\
\text { K.L. } \\
\text { D.Bo. } \\
\text { S.E. }\end{array}$ & $\begin{array}{r}39,000 \\
17,000 \\
190,000 \\
2,000 \\
11,000 \\
24,000 \\
42,000 \\
230,000 \\
53,000 \\
18,000 \\
26,000 \\
55,000 \\
260,000 \\
104,000 \\
330,000\end{array}$ & $\begin{array}{r}22,000 \\
34,000 \\
32,000 \\
7,000 \\
23,000 \\
31,000 \\
17,000 \\
45,000 \\
95,000 \\
12,000 \\
61,000 \\
41,000 \\
99,000 \\
19,000 \\
1,100,000\end{array}$ & $\begin{array}{r}17,000 \\
75,000 \\
8,000 \\
14,000 \\
69,000 \\
172,000\end{array}$ & 16,000 & 15,000 \\
\hline $\begin{array}{l}\text { R.F. } \\
\text { P.N. } \\
\text { J.F. } \\
\text { D.McC. } \\
\text { W.H. }\end{array}$ & $\begin{array}{r}460,000 \\
570,000 \\
660,000 \\
1,400,000 \\
3,100,000\end{array}$ & $\begin{array}{r}290,000 \\
96,000 \\
2,000,000 \\
79,000 \\
170,000\end{array}$ & 35,000 & & \\
\hline
\end{tabular}

presumably, of renal size. The majority of adults have urinary white cell excretion rates of less than 200,000 cells/hr., and though a few exceed this value it rarely reaches more than 400,000 cells $/ \mathrm{hr}$. (Houghton and Pears, 1957; Hutt et al., 1961; Little, 1962). Even the lower of these figures would be quite abnormal for a small child or infant and a separate set of standards must be applied to results obtained from children. Infants up to $36 \mathrm{in}$. $(91 \mathrm{~cm}$.) or $0.55 \mathrm{sq} . \mathrm{m}$. in height or surface area respectively rarely exceed an excretion rate of 50,000 white cells/hr.; with increasing size the acceptable
TABLE 2

URINARY WHITE CELL EXCRETION RATES, CONSECUTIVE SPECIMENS OVER A 24-HOUR PERIOD*

\begin{tabular}{|c|c|c|c|c|c|}
\hline \multirow{2}{*}{$\begin{array}{c}\text { Time } \\
\text { of } \\
\text { Day }\end{array}$} & \multicolumn{5}{|c|}{ White Cell Excretion Rate (cells/hr.) } \\
\hline & P.C. & M.J. & M.F. & P.N. & M.G. \\
\hline A.M. & $\begin{array}{r}12,000 \\
5,000\end{array}$ & $\begin{array}{r}8,000 \\
61,000 \\
41,000\end{array}$ & $1,500,000$ & $\begin{array}{l}35,000 \\
16,000 \\
14,000\end{array}$ & $\begin{array}{l}27,000 \\
50,000\end{array}$ \\
\hline \multirow{2}{*}{ P.M. } & 33,000 & $\begin{array}{l}29,000 \\
16,000\end{array}$ & $\begin{array}{l}260,000 \\
200,000 \\
510,000\end{array}$ & 7,000 & $\begin{array}{l}80,000 \\
29,000 \\
21,000\end{array}$ \\
\hline & $\begin{array}{l}10,000 \\
21,000\end{array}$ & 7,000 & $\begin{array}{r}1,040,000 \\
660,000\end{array}$ & 6,000 & \\
\hline A.M. & 9,000 & 18,000 & $\begin{array}{l}700,000 \\
320,000\end{array}$ & & \\
\hline
\end{tabular}

* In 4 of the 5 patients, the highest rate was recorded between 6 a.m. and midday.

upper limit gradually increases to 100,000 white cells $/ \mathrm{hr}$. for a child of $45 \mathrm{in}$. $(114 \mathrm{~cm}$.) or $0.8 \mathrm{sq} . \mathrm{m}$. and eventually reaches an approximately adult level with a height of about $52 \mathrm{in} .(132 \mathrm{~cm}$.) or a surface area of $1.0 \mathrm{sq}$. $\mathrm{m}$. (approximately 8 to 10 years of age). The only comparable report on this subject is that of Gekle (1964) who, from 50 children (2 to 14 years old) obtained figures to suggest that 40,000 white cells/hr. was the normal upper limit of white cell excretion. His results are compatible with the hypothesis that body (or renal) size is a factor in determining white cell excretion; the discrepancy in results in later childhood between that report and the present one may be attributable to the difference in numbers of specimens examined or possibly to the fact that catheterization was the method by which specimens were obtained by Gekle.

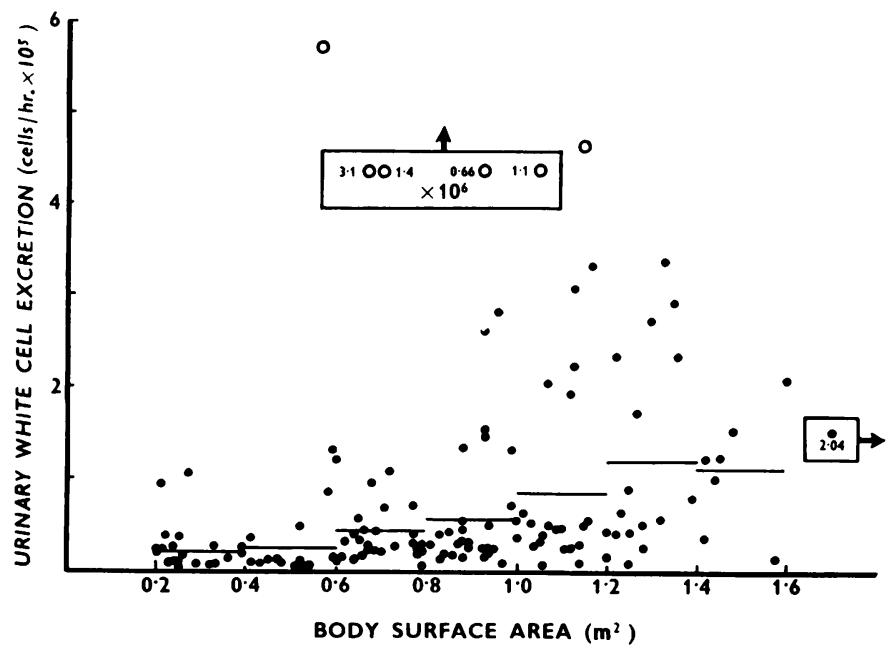

Fig. 4.-Relationship of white cell excretion to surface area. The mean values for patients in 0.2 sq. $\mathrm{m}$. groups is shown by the horizontal lines. They are respectively (from the left) $20,000,24,000,45,000,58,000,87,000,120,000$, and 112,000/hour. 
There is a disappointingly wide variation in excretion rates in the same child on different days and even at different times of the same day, which makes changes of excretion rate induced by prednisolone or bacterial pyrogen difficult to evaluate. It is desirable not to rely too heavily on the results of a single observation in assessing renal status, though a repeat measurement will usually yield a result sufficiently like the first to say with some certainty that it is, or is not, normal.

As will be seen, the measurement of white cell excretion in the urine has drawbacks, but if the correct set of standards for the child's size are applied, this sensitive technique can supply very valuable information.

\section{Summary}

A set of standards is described relating urinary white cell excretion rates to the size of the child. Though the variation in excretion rates in the same child at different times is sometimes appreciable, the results can usually be quite easily interpreted and can be of great assistance in assessing cases of 'subclinical' renal disease.

I should like to thank Dr. H. B. Marsden for his helpful advice and for permitting me to use the facilities of his laboratory. My appreciation is also due to Professor Wilfrid Gaisford for his support and assistance and to the Department of Medical Illustration, Manchester Royal Infirmary, for the figures.

\section{REFERENCES}

Gekle, D. (1964). Untersuchungen über die physiologische Leukocyturie im Kindesalter und die Beeinflussung der Leukocytenausscheidung durch Prednisolon bei chronischer Pyelonephritis. Ann. paediat. (Basel), 203, 113.

Hodson, C. J., Drewe, J. A., Karn, M. N., and King, A. (1962). Renal size in normal children; a radiographic study during life. Arch. Dis. Childh., 37, 616.

Houghton, B. J., and Pears, M. A. (1957). Cell excretion in normal urine. Brit. med. J., 1, 622.

Hutt, M. S. R., Chalmers, J. A., MacDonald, J. S., and de Wardener, H. E. (1961). Pyelonephritis. Lancet, 1, 351.

Katz, Y. J., Velasquez, A., and Bourdo, S. R. (1962). The prednisolone provocative test for pyelonephritis. ibid., 1, 1144 .

Little, P. J. (1962). Urinary white-cell excretion. ibid., 1, 1149.

- , and de Wardener, H. E. (1962). The use of prednisolone phosphate in the diagnosis of pyelonephritis in man. ibid., 1 , 1145. 